\title{
The social production of innovation: the electric automobile and innovation networks in Brazil
}

\section{Rodrigo Foresta Wolffenbüttel* (1)}

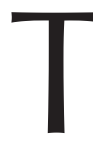

oday one sees a new and instigating phenomenon in the automotive market, that is already felt in Brazil: the development and use of electric automobiles. According to data of the International Energy Agency (IEA), nearly 2 million electric cars were sold worldwide in 2018, which represents a 68\% increase over the figure for 2017 (IEA, 2019). The ascent of electric motors is related to a series of social, political, and economic questions that have pressured the automotive market and its operation. These questions have to do with the development of new technologies and products that challenge competitors in this market, as well as a series of environmental, urban mobility, and public health problems derived from the mass production and individual use of internal combustion vehicles.

Concerned about these issues, but also attentive to related possibilities for technological development, many countries and companies started to see investment in "green" technologies, especially energy technologies, as a strategic route to economic growth. Large markets, such as China, the

\footnotetext{
*Universidade Federal do Rio Grande do Sul, Porto Alegre, RS, Brasil.
} 
United States and Japan (responsible for the three largest fleets of electric vehicles), have moved toward automobile electrification. According to reports such as the Global EV Outlook (IEA 2019), the growing presence of electric vehicles in these countries is due largely to the conjuncture of ambitious goals and policies providing incentives for low emission vehicles. These policies include subsidies for the purchase of electric vehicles, tax reductions, regulatory measures limiting gas emissions, exemption from parking fees, as well as areas with circulation limited to electric vehicles and the installation of public charging stations. Implemented in different ways and with the participation of different local actors, these sets of policies produce distinct institutional contexts and market configurations for the establishment of the electric automobile.

Despite Brazil being the eighth largest vehicle market in 2018, with over 2,566,000 sold (ANFAVEA, 2020), the market share of electric vehicles in that year was only $0.02 \%$, a small number compared to sales in other emergent economies, such as China and India, with electric vehicle sales in 2018 of $4.48 \%$ and $0.10 \%$, respectively (IEA, 2019). These data reveal a certain inertia in the Brazilian automotive market in the face of a possible technological transition to electric mobility, stimulating this research on the factors that contribute to this market situation. This project explores the possibilities and limits faced by networks of actors attempting to implement the electric car in Brazil.

Much more than abstract mechanisms for price regulation, markets, for Economic Sociology, are spaces of structured social relations, in which specific goods and services are distributed through commercial exchange. These social exchange relations are marked by price struggles, by competition between differently positioned social actors positions, and by regulation within specific social orders. Therefore, the marketability of specific goods and services, conditions of exchange, and participation in markets of interested parties are regulated and limited by social orders legitimated by traditions, conventions, and norms. Markets are structured within institutional arrangements that guarantee and regulate relations of competition and 
cooperation through administrative structures, laws, barriers to commerce, property rights, antitrust laws, and the like.

The ways in which these institutional arrangements are structured over time, with greater or lesser openness in relation to participants, different forms of state intervention and different patterns of interest mediation, affect the conditions for disputes among market actors, who constantly attempt to influence the content of these forms of regulation and their applicability (Fligstein, 2001). In the development and application of a technological change, such as the electric automobile, these arrangements imply, aside from the dispute for market positions between challengers and established players, that this dispute occurs in spaces that can favor or disfavor the emergence of certain technological innovations.

However, this does not mean that market structuring determines the process of innovation. Instead, innovation occurs within this space of relations, where social actors coordinate their action (dispute, cooperate, negotiate), based on shared understandings about these interactions, which vary as these actors relate their competencies, complementarities and interests to the order established in the market.

In the case of the Brazilian automotive market, this analysis of institutional arrangements highlights certain aspects of their configuration that tend to impede the activities of innovative actor networks and operate as obstacles to the introduction of technological alternatives to the gasoline powered automobile. These alternative networks are mostly formed by actors external or secondary to the automotive market, such as electricity companies, suppliers of electrical equipment, consumer associations, research institutes, and subnational public administrations, which join together in attempting to overcome the obstacles of existing institutional arrangements. These institutional obstacles include the corporativist relations between the automotive industry and the federal government; the high degree of international technological dependency; the establishment of an alternative technological path with regard to mobility electrification; and the vague position of the national state with regard to technological transition. 
From its beginnings, the Brazilian automotive market has been an important vector for economic development and modernization of the country. The state participated in this process by formulating regulations to attract foreign technology and producers, by investing in infrastructure and basic industries, and by implementing rules that fomented consumption and popularized the domestically manufactured auto as a symbol of modernity.

This involvement of the federal government contributed to the consolidation of a pattern of corporatist industry-government mediation, marked by negotiation with only a few partners and oriented to consensus formation. Large corporations coordinated their relations with the government and negotiated to promote their interests, represented by a couple of powerful associations - the National Association of Automotive Vehicle Manufacturers (Anfavea - Associação Nacional dos Fabricantes de Veículos Automotores) and the National Union of the Automotive Vehicle Components Industry (Sindipeças - Sindicato Nacional da Indústria de Componentes para Veículos Automotores). These associations exercise an important influence on the forms of regulation and the shared understandings of industry and government. This arrangement tends to prioritize the interests of established firms and benefits existing technological regimes in detriment to possible challengers (Meckling; Nahm, 2017).

In addition, the market was shaped through a pattern of corporatist governance that has lasted until today. The large international manufacturers, controlled from their foreign headquarters, came to dominate the domestic Brazilian automobile market, with notable participation of the "four giants" - General Motors, Ford, Volkswagen and, later on, Fiat - in production for the mass market. This form of dependency, with external control, ended up influencing the dynamics of development and technological change in the market. Relatively protected by government policies and financially controlled by foreign centers of executive decision, the manufacturers installed in Brazil mostly used automobile projects developed in other countries that went through adaptations for the Brazilian market. This has occurred since the formative period of the market, and during the movement toward market opening, up to the period of Inovar-Auto, a sectoral policy 
oriented toward technological development and protection of domestic production, which promoted energy efficiency (15.4\%, according to a study of the Brazilian Association of Automotive Engineering) of the national fleet through technology transfer from company headquarters.

An important exception to this dynamic of adaptation was the development and perfection of flex-fuel technology, which allows internal combustion engines to use more than one type of fuel. This technology was preceded by the Proálcool program (a Brazilian government initiative, established in 1975, to stimulate ethanol production for alcohol-fueled cars) and consolidated a configuration of expertise, infrastructure and understandings in relation to biofuels (ethanol) as an alternative source of energy for motor vehicles. Investment in this technology produced important interdependencies between the national automotive market and the sugar and alcohol sector, which historically exercised great influence over public policies by way of corporativist arrangements, such the Próalcool program (Barcelos 2015). This sector is directly interested in the consolidation of ethanol as an alternative fuel for reduction of the pollution caused by motor vehicles.

This kind of interdependence of trajectories (Cowan; Hulten, 1996) contributes to the unclear position of the Brazilian state in relation to technological transition. The principal industrial policy for the sector, the Rota 2030 program, does not articulate a clear direction for technological change. Instead, one sees a set of generic policies and initiatives, oriented toward increased energy efficiency and the reduction of emissions (the Vehicle Tagging Program; the Motor Vehicle Air Pollution Control Program). In response to this vague signaling by the state, the posture of manufacturers established in the domestic market can be considered strategically ambiguous. They have established a few experimental programs and, more recently, have been selling a few imported models, mostly high-performance hybrid cars with prices far above what the mass market can bear.

The current institutional arrangement configuring the Brazilian automotive market thus produces relatively protected and technologically dependent firms, in a space of corporativist state-industry relations, which 
is unfavorable to innovation networks oriented to the development and diffusion of the electric car. This tends to favor the perpetuation of the internal combustion motor, with incremental innovations such as the flexfuel automobile, and support for ethanol as the favored technological alternative, due to its previously established advantages in Brazil.

Rodrigo Foresta Wolffenbüttel holds a doctorate in Sociology from the Federal University do Rio Grande do Sul (UFRGS) and is currently a Technician for Educational Issues at the Department fo Distance Education at UFRGS.

$\triangle$ rodrigoforesta@gmail.com

\section{References}

1. ANFAVEA - Associação Nacional dos Fabricantes de Veículos Automotores. Anuário da Indústria Automobilística Brasileira. São Paulo: AutoData Editora, 2020.

2. BARCELOS, Márcio. Ideias, agendas e políticas públicas: um estudo sobre a área de biocombustíveis no Brasil. Thesis (Doctorate in Sociology), Federal University of Rio Grande do Sul, 2015.

3. COWAN, Robin; HULTÉN, Staffan. Escaping the lock-in: the case of the electrical vehicle. Technology Forecasting and Social Change, v. 53, n. 1, p. 63-79, 1996.

4. FLIGSTEIN, Neil. Mercado como política: uma abordagem político cultural das instituições de mercado. Contemporaneidade e Educação, v. 6, n.9, p. 26-55, 2001.

5. IEA - International Energy Agency. Global EV Outlook 2019. Scaling-up the transition to electric mobility. Paris: OECD Publishing, 2019.

6. MECKLING, Jonas; NAHM, Jonas. When do states disrupt industries? Electric cars and the politics of innovation. Review of International Political Economy, v. 25, n. 4, p. 505-529, 2017. 